\title{
Improvement of Catalytic Efficiency, Thermo-stability and Dye Decolorization Capability of Pleurotus ostreatus IBL-02 laccase by Hydrophobic Sol Gel Entrapment
}

Muhammad Asgher, Shagufta Kamal and Hafiz Muhammad Nasir lqbal*

\begin{abstract}
Background: In serious consideration of the worldwide environmental issues associated with the extensive use of the textile dyes and effluents generated thereof, the scientists across the world are in search for potential treatment technologies for their treatment. In such scenario the ligninolytic enzymes provide a potential alternative because they are cost effective, eco-friendly and can be applied to wide range of dye containing industrial effluents.

Results: Laccase produced from Pleurotus ostreatus IBL-02 during decolorization of the reactive textile dye Drimarene brilliant red K-4BL (DBR K-4BL) was purified and immobilized by hydrophobic gel entrapment. The crude laccase was 4.2-fold purified with specific activity of $573.52 \mathrm{U} / \mathrm{mg}$ after passing through the DEAE-Sepharose ion exchange and Sephadex-G-100 chromatography columns. P. ostreatus IBL-02 laccase was found to be a homogenous monomeric protein as evident by single band corresponding to $67 \mathrm{kDa}$ on native and sodium dodesylsulfate polyacrylamide gel electrophoresis (PAGE). The laccase was immobilized by entrapment in Sol-gel matrix of trimethoxysilane $(T)$ and proplytetramethoxysilane $(P)$ prepared using different T:P molar ratios. The free and immobilized laccases were compared to investigate the effect of immobilization on catalytic efficiency and thermo-stability features. Laccase immobilized in the Sol-gel of 1:5 T:P ratio was optimally active and thermo-stable fraction at pH $5,60^{\circ} \mathrm{C}$ with half-life of $3 \mathrm{~h}$ and 50 min. Laccases immobilized in 1:2 and 1:5 T:P ratio gels had significantly higher $K_{\mathrm{m}}\left(83\right.$ and100mM) and $V_{\max }(1000$ and $1111 \mathrm{mM} / \mathrm{mg})$ values as compared to free laccase. After $5 \mathrm{~h}$ reaction time varying decolorization percentages with a maximum of $100 \%$ were achieved for different dyes and effluents.
\end{abstract}

Conclusions: In summary, P. ostreatus IBL-02 laccase was immobilized by entrapping in a Sol-gel matrix with an objective to enhance its catalytic and stability properties. Sol-gel entrapped laccase presented potential efficiency as a biocatalyst when applied for decolorization of different dyes and effluents. The main benefits of the Sol-gel matrix immobilization processes are the eco-friendly approach, chemical free and energy saving reaction conditions.

Keywords: P. ostreatus IBL-02, Laccase, PAGE, Sol-gel immobilization, Kinetics, Textile dye, Waste water effluent, Decolorization

\footnotetext{
* Correspondence: nasir_pk99@hotmail.com

Industrial Biotechnology Laboratory, Department of Chemistry and

Biochemistry, University of Agriculture, Faisalabad, Pakistan
} 


\section{Background}

Laccase (EC 1.10.3.2) is a blue copper oxidase secreted by white rot fungi (WRF) not only an important component of the ligninolytic enzyme system responsible for lignin degradation, but can even degrade non-aromatic compounds in the presence of low molecular weight redox mediator compounds [1]. As single enzyme and/ or in combination with other ligninolytic, cellulolytic and xylanolytic enzymes, laccases have important applications in bio-ethanol production, bio-pulping in the paper and pulp industry, denim stone washing, wastewater treatment, oxidation of organic pollutants, extraction and stabilization of fruit juices, biosensor development, textile bio-finishing, beverage processing, decreasing dough extensibility in flour, animal feed, cosmetics, clinical diagnosis enzyme immunoassays, and detergent manufacturing [2-8]. However, their high production cost, low operational stabilities, availability in small amounts, susceptibility to attack by proteases and activity inhibition limit their commercial applications in industrial and environmental biotechnology [9].

Over the last few decades, intensive research in the area of enzyme technology has provided many approaches that facilitate their practical applications. The various techniques for enhancing operational stability of laccases are enzyme engineering, chemical modification, mutation and immobilization [10]. Among them, the newer technological developments in the field of immobilized biocatalysts can offer the possibility of a wider and more economical exploitation of biocatalysts in industry, waste treatment, medicine, and in the development of bioprocess monitoring devices like biosensors [11]. The method of immobilization is the most important because equipped steadiness and reusability of enzyme depend on it. Physical entrapment and surface binding are the two most commonly used methods. Entrapment is preferred over surface binding as this method is easier and cheaper, stable derivatives are formed and the structure of the enzyme remains secure [12]. A second important component of immobilization on which performance of the enzyme depends, is enzyme support. Two types of commonly used supports are hydrophobic and hydrophilic biomaterials. Hydrophobic biomaterials are preferred because these have the ability to entrap large amounts of enzyme with a much higher degree of immobilization and enzyme activity retention. The physical characteristics of Sol-gels have been extensively manipulated for enzyme immobilization and these gels have attracted the attention of biotechnologists. Sol-gels have the ability to produce enzymes in stable defined thin films that are more vigorous having ability to catalyze reactions under wide environmental conditions $[13,14]$.

Dye containing textile waste effluents contain several types of hazardous chemicals including synthetic dyes
[14]. Most of the textile industries discharged their routine waste effluents into the main water streams without or after some partial chemical / physical treatments. An eco-friendly treatment of industrial effluents is still a major environmental concern for modern world [15]. In spite of the existing physical/chemical technologies that are usually expensive and commercially or environmentally unattractive, biological processes seem as potential alternatives because they are cost effective, eco-friendly and can be applied to wide range of dye containing industrial effluents. WRF have the ability to degrade contaminants by virtue of its extracellular ligninolytic enzymes including lignin peroxidases (LiPs), manganese peroxidases (MnPs) and laccases [6,13-16]. Therefore, over the past several years, there has been great interest among researchers in the production of ligninolytic enzymes using various agro-based waste materials [5].

This manuscript describes the results of a study aimed at immobilizing a laccase, produced by the indigenous strain of $P$. ostreatus IBL-02 during decolorization of Drimarene brilliant red K-4BL [17] in Sol-gels matrix of varying hydrophobicities. The investigation also involved the comparison of kinetic, catalytic and thermo-stability properties of immobilized and free laccases and, their abilities to decolorize different textile dyes and industrial effluents.

\section{Results and discussion}

\section{Source of laccase}

The laccase produced by $P$. ostreatus IBL-02 during decolorization of Drimarene brilliant red K-4BL under optimum conditions [17] was used for purification, immobilization and characterization studies. Under optimum conditions, $P$. ostreatus IBL-02 produced 321 $\mathrm{U} / \mathrm{mL}$ of laccase during complete decolorization $(100 \%)$ of Drimarene Brilliant Red K- 4BL in $24 \mathrm{~h}$. The optimum conditions were: glucose (as carbon supplement), $2 \mathrm{~g} /$ $100 \mathrm{~mL}$; ammonium nitrate (nitrogen additive), $0.06 \mathrm{~g} /$ $100 \mathrm{~mL} ; \mathrm{Cu}^{2+}(1 \mathrm{mM}), 1 \mathrm{~mL}$ as metal activator; ABTS $(10 \mathrm{mM}), 2 \mathrm{~mL}$ as mediator, $\mathrm{pH} 5$ and temperature, $35^{\circ} \mathrm{C}$. The culture supernatant was used as crude enzyme extract for purification and immobilization purposes.

\section{Purification of laccase}

Crude laccase was purified to homogeneity after ammonium sulfate precipitation, dialysis, DEAE-Sepharose ion exchange chromatography and Sephadex G-100 gel filtration. The four step purification protocol for laccase resulted in 4.2 fold purification (Table 1) with $11 \%$ laccase recovery. The onset of laccase precipitation occurred at $50 \%$ saturation, while complete salting out was observed at $80 \%$ saturation. The short range of precipitation i.e., from $50-80 \%$ provided evidence that there might be only one form of laccase having the same level 
Table 1 Purification summary for laccase produced by $P$. ostreatus IBL-02 during decolorization of DBR K- 4BL

\begin{tabular}{|c|c|c|c|c|c|c|}
\hline Purification steps & $\begin{array}{l}\text { Total volume } \\
(\mathrm{mL})\end{array}$ & $\begin{array}{l}\text { Total enzyme } \\
\text { activity (U) }\end{array}$ & $\begin{array}{l}\text { Total protein } \\
\text { content }(\mathrm{mg})\end{array}$ & $\begin{array}{l}\text { Specific activity } \\
\text { (U/mg) }\end{array}$ & $\%$ Yield & $\begin{array}{l}\text { Purification } \\
\text { fold }\end{array}$ \\
\hline Crude Enzyme & 500 & 62500 & 2360 & 134.95 & 1 & 100 \\
\hline$\left(\mathrm{NH}_{4}\right)_{2} \mathrm{SO}_{4}$ & 30 & 48060 & 138 & 348.26 & 2.5 & 76 \\
\hline \multicolumn{7}{|l|}{ Precipitation } \\
\hline DEAE-Sepharose & 12 & 9440 & 20.34 & 464.11 & 3.4 & 15 \\
\hline Sephadex-G-100 & 09 & 7020 & 12.24 & 573.52 & 4.2 & 11 \\
\hline
\end{tabular}

of surface charge. After the removal of salts by dialysis, its purification factor and percent recovery were increased. Ammonium sulfate saturation to $80 \%$ resulting in $76 \%$ yield was selected for further purification. Purification of laccase after ion exchange chromatography was about 3.4 fold and its recovery was $15 \%$. Ion exchange chromatography played an important role in the separation of the blue-colored fraction with laccase activity from the dark brown pigments. By gel filtration through a G-100 Sephadex column laccase was purified to $4.2 \sim$ fold with $11 \%$ recovery.

A variety of purification techniques including, ammonium sulfate precipitation, gel filtration and ion exchange chromatography are required to purify laccase from other pigments and contaminating proteins. In line with our findings, Chen et al. [18] also reported $80 \%$ as the saturation point of ammonium sulfate for laccase isolation from $P$. ostreatus. Mansur et al. [19] reported that ammonium sulfate precipitation provided $57 \%$ yield with a $5 \sim$ folds purification of laccase.

\section{Native and SDS-PAGE}

Laccase was purified to an apparent homogeneous level and the purity was confirmed on $12 \%$ native and $10 \%$ SDS-PAGE, respectively. The single band of $67 \pm 1 \mathrm{kDa}$ on Native and SDS-PAGE confirmed that P. ostreatus IBL-02 laccase was a monomeric protein (Figure 1). Similar with our findings, the laccases isolated from different strains and species of Pleurotus have been found to be monomeric in nature with molecular masses in $53-67 \mathrm{kDa}$ range [3,20]. Laccases having molecular masses of $53 \mathrm{KDa}$ from Lentinula edodes have been reported by Nagai et al. [21]. As compared to these, laccases of much higher masses including $72 \mathrm{kDa}$ from $F u$ sarium solani [22] and $94 \mathrm{kDa}$ for Phanerocheate flavidoalba [23] have also been isolated.

[Lane 1, Molecular weights in kDa of standard marker; ( $\beta$-Galactosidase, 116 kDa; Phosphorylase B, 97 kDa; albumin, $66 \mathrm{kDa}$; ovalbumin, $45 \mathrm{kDa}$; carbonic anhydrase, $30 \mathrm{kDa}$ and trypsin inhibitor, $21 \mathrm{kDa}$ ); lane 2, Crude enzyme extract; lane 3 and 4, Purified Laccase in SDSPAGE; lane 2 and 3 in native PAGE, Purified Laccase $(67 \mathrm{kDa})]$.

\section{Immobilization of laccase}

The purified $P$. ostreatus IBL-02 laccase was immobilized in sol-gels of varying hydrophobicities. Specific activities of laccase immobilized in different gels are

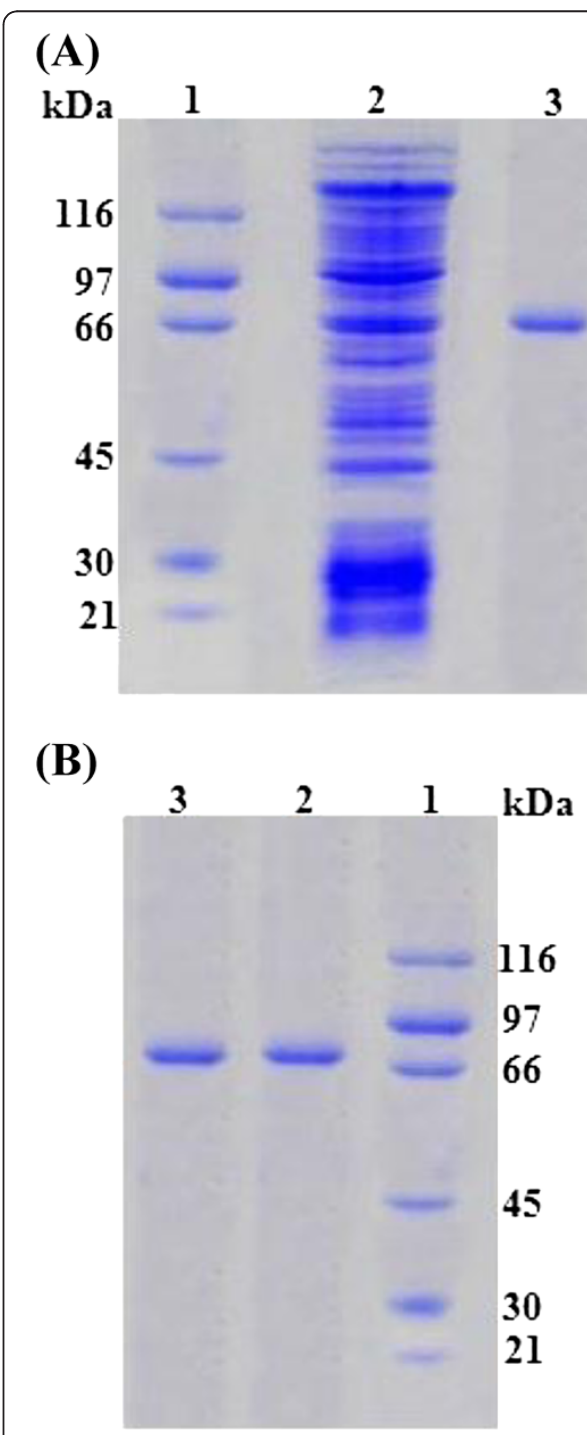

Figure 1 SDS (A) and Native (B) PAGE for Laccase produced by $P$. ostreatus IBL-02. 
shown in (Table 2). The specific activity of immobilized laccase was higher as compared to free enzyme and it increased by increasing T:P ratio from 1:1 to 1:5 (increasing hydrophobicity of the Sol-gels). However, with increasing hydrophobic character (higher $\mathrm{T}$ : $\mathrm{P}$ ratios), the specific activity of immobilized laccase significantly decreased, possibly due to diffusion limitation barrier created by increasing the hydrophobic nature of the gel. Maximum specific activity (1326 U/mg) was observed for laccase entrapped in the Sol-gel matrix of 1:5 T:P ratio. The degree of immobilization was not dependent on the amount of protein immobilized and there was no significant effect of increasing the amount of protein on the catalytic activity of enzyme after certain limits. Smaller values of specific activity with higher degree of immobilization were due to the fact that smaller concentration of substrate could enter into the catalytic site of the enzyme. When the concentration of enzyme was high in the Sol-gel, the enzyme was present in an aggregated form rather than in a dispersed form, leading to lower activity by increasing the extent of immobilization. As laccases entrapped in 1:1, 1:2, 1:5 T:P ratio gels had higher specific activities than laccases immobilized in the rest of the gels, laccases immobilized in these gels were selected for characterization.

Entrapment of laccase in Sol-gels involves adsorption phenomenon that has been reported as the best method for immobilization of laccase [24]. Previously, we [16] reported that entrapment of lignin peroxidase (LiP) from $P$. chrysosporium in Sol-gels caused hyper-activation but an increase in hydrophobic character above certain optimum limits caused a decrease in LiP activity. As the concentration of silane increases, the degree of immobilization also increases but the activity of enzyme decreases [25]. However, the covalent binding strategy is much more expensive because it requires glutareldehyde as coupling agent.

\section{Characterization of free and immobilized laccase Effect of $\mathrm{pH}$ on free and immobilized laccase}

Free and immobilized laccases showed different $\mathrm{pH}$ activity profiles. The observed $\mathrm{pH}$ optima for free and immobilized enzymes (1:5 T:P ratio) were 6 and 4, respectively (Figure 2). Immobilization caused a decrease in optimum $\mathrm{pH}$ and there was a shift from less acidic towards more acidic optimum $\mathrm{pH}$. All three laccases entrapped in varying T:P ratio gels showed broader $\mathrm{pH}$ ranges than free laccase. The method of immobilization and ionic or hydrogen bonding (secondary interaction) may be responsible for this shift in optimum $\mathrm{pH}$ from less acidic to more acidic. Rekuc et al. [26] also reported that after immobilization, the optimum $\mathrm{pH}$ of laccase shifted toward the acidic range and this shift was due to the buffering effect of the carrier surface. Contrary to our results, Qiu et al. [24] found that immobilized as well free laccase showed similar $\mathrm{pH}$-activity profiles because of the clear surface of the nanoporous gold immobilization support used by them.

\section{Effect of temperature on free and immobilized laccase}

Effect of temperature was studied for immobilized and free laccase in the range of $25-75^{\circ} \mathrm{C}$ (Figure 3). There was a shift of optimum temperature optimum from $45^{\circ} \mathrm{C}$ to $60^{\circ} \mathrm{C}$ due to immobilization and immobilized laccase was more thermos table than free laccase. Laccase entrapped in Sol-gel of 1:5 P:T ratio was the most thermos table. The order of thermo-stability was 1:5 laccase $>1: 2$ laccase $>1: 1$ laccase. The immobilized laccase had a $20^{\circ} \mathrm{C}$ rise in optimum temperature when compared with free laccase, suggesting that immobilization of laccase in hydrophobic Sol-Gels made it more suitable candidate for industrial application. Free laccase lost its activity at temperatures above $45^{\circ} \mathrm{C}$ but immobilized laccase was fully active at $60^{\circ} \mathrm{C}$ due to the fact that external backbone of laccase became more protected and the entrapped enzyme became more resistant to heat. Half-lives at $60^{\circ} \mathrm{C}$ were also

Table 2 Activities of $P$. ostreatus IBL-02 laccase immobilized in sol-gels of different hydrophobicities

\begin{tabular}{llllll}
\hline No. & $\begin{array}{l}\text { Gel precursors } \\
\text { TMOS:PTMS (molar ratio) }\end{array}$ & $\begin{array}{l}\text { Specific activity } \\
(\mathbf{U} / \mathbf{m g})\end{array}$ & $\begin{array}{l}\text { Degree of } \\
\text { immobilization }\end{array}$ & $\begin{array}{l}\text { Specific activity } \\
\text { corrected* (U/mg) }\end{array}$ & $\begin{array}{l}\text { Relative } \\
\text { activity }\end{array}$ \\
\hline 1 & Free laccase & 573 & & 573 & 1 \\
2 & $1: 1$ & 335 & 0.41 & 670 & 2.5 \\
3 & $1: 2$ & 317 & 0.44 & 720 & 2.7 \\
4 & $1: 5$ & 398 & 0.30 & 1326 & 3.3 \\
5 & $1: 10$ & 288 & 0.49 & 587 & 2.0 \\
6 & $1: 15$ & 170 & 0.52 & 326 & 1.9 \\
7 & $1: 20$ & 149 & 0.56 & 266 & 1.7 \\
8 & $1: 25$ & 97 & 0.58 & 167 & 1.7 \\
9 & $1: 30$ & 11 & 0.63 & 17 & 1.5 \\
\hline
\end{tabular}

"Activities were corrected with degree of immobilization. 


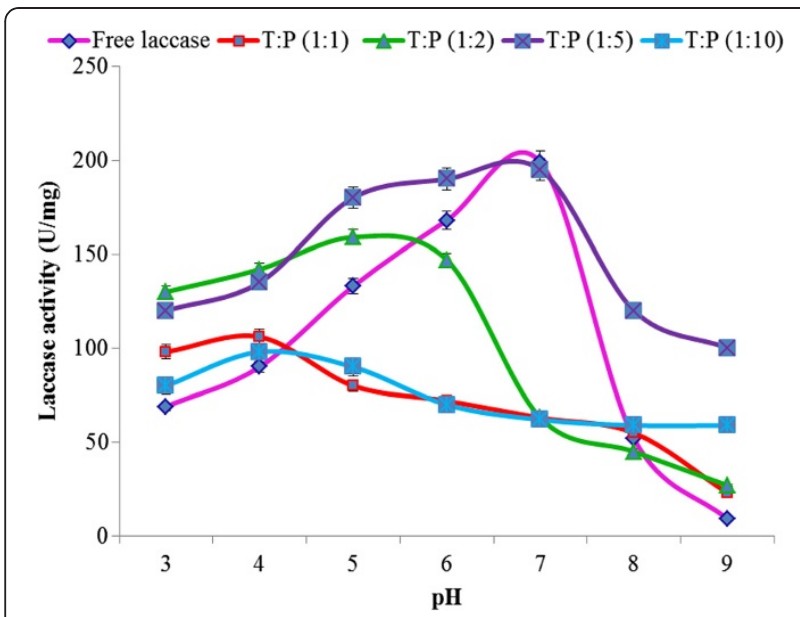

Figure 2 Effect of $\mathrm{pH}$ on activities of immobilized and free laccases.

calculated for both entrapped and soluble lacccase as shown in Figure 4 . It was approximately $3 \mathrm{~h}$ and $10 \mathrm{~min}$ for 1:2 T:P ratio and $3 \mathrm{~h}$ and $50 \mathrm{~min}$ for 1:5 T:P ratio, as compared to only $40 \mathrm{~min}$ for free laccase at $60^{\circ} \mathrm{C}$. Laccase immobilized in 1:2 and 1:5 T:P ratios were, therefore, selected for kinetic characterization.

To make an enzyme industrially applicable, temperature is one of the most important parameters to determine the thermo-stability of the enzyme. Although it is the effect of temperature that determines which proteins lose their three dimensional structure, its effect became negligible in case of laccase due to hydrophobic interaction of laccase with the gel material that may stabilize the three dimensional structure of the enzyme. Immobilization enhances thermo-stability because maintenance of the three dimensional structures of protein competes with denaturation and loss of catalytic activities

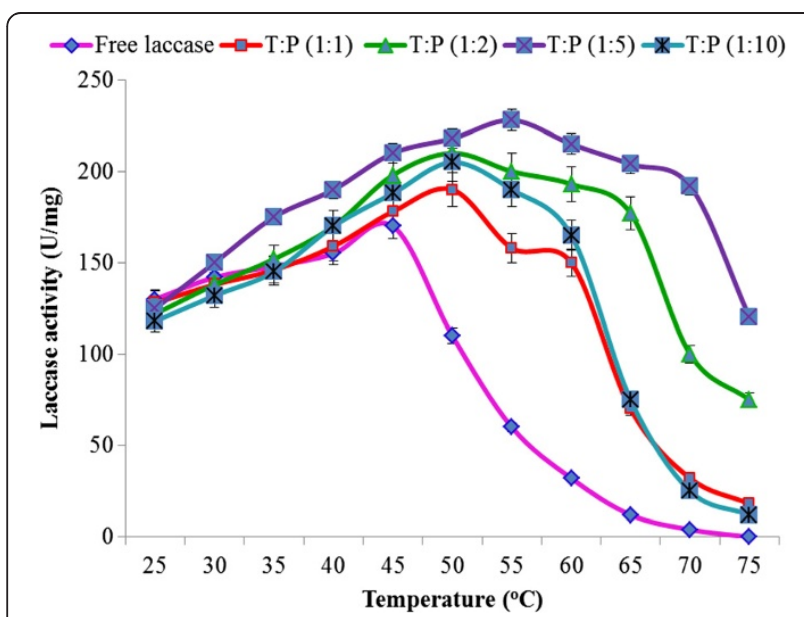

Figure 3 Effect of temperature on activities of immobilized and free laccases.

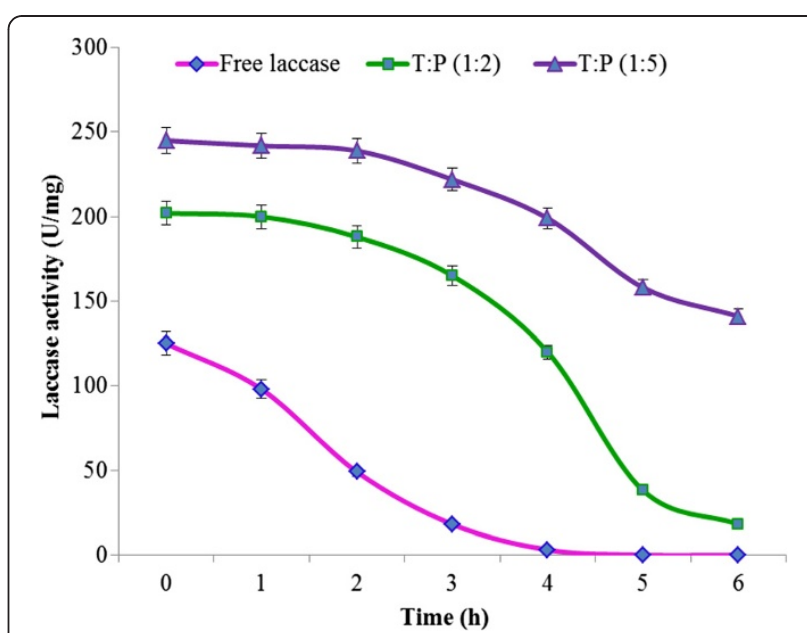

Figure 4 Study of half-lives of immobilized and free laccases.

of the proteins [27]. Arica et al. [28] reported that immobilized laccase lost its activity at a mud slower rate than free enzyme by the rise in temperature. In line with our findings, immobilized laccase has been reported to withstand a wider range of temperatures $\left(50 \sim 80^{\circ} \mathrm{C}\right)$ than free laccase [29]. Immobilization probably prevents unfolding of laccase that results in a longer half-life as compared to free laccase [30].

\section{Effect of substrate concentration: Determination of $K_{m}$ and} $V_{\max }$

Kinetics of entrapped/free laccase was found to be affected by the rate of diffusion of ABTS to the enzyme active site entrapped in the Sol-gel matrices of various hydrophobicities. Results shown in (Figure 5) indicated that laccases entrapped in 1:2 and 1:5 T:P ratio gels had more affinity for ABTS but their interaction decreases

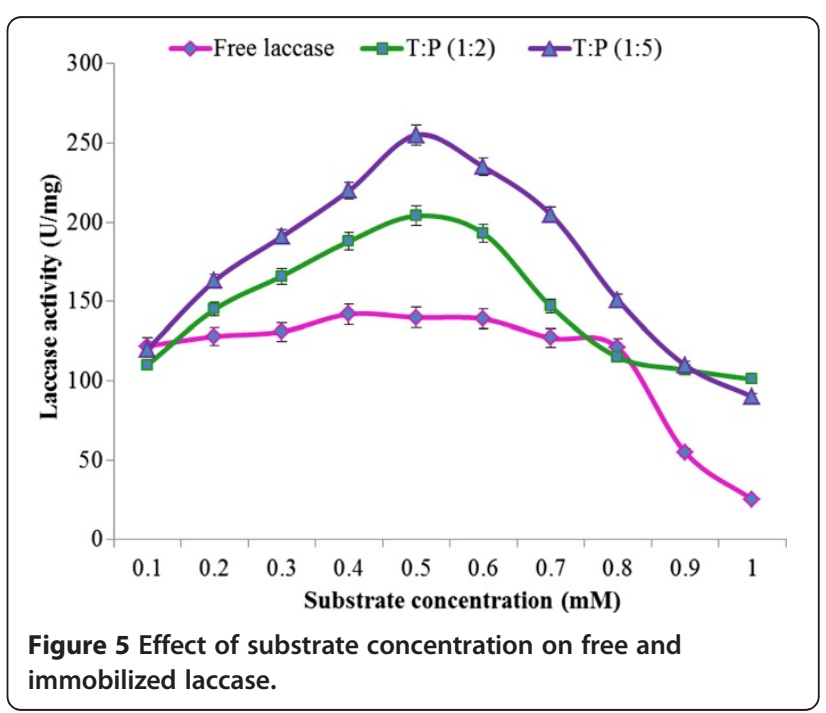


with further increase in gel hydrophobicity. It was noticed that entrapped laccase was highly active having higher $\mathrm{V}_{\max }$ values with lower ABTS concentrations range as compared to free laccase, but the reaction rate decreased with high substrate concentrations. Higher substrate concentrations may have created steric hindrance in the access of the substrate to the enzyme active site due to diffusion limitations of the substrate into the gel matrix.

Classical Lineweaver-Burk plot transformation of the Michaelis-Menten rate equation was used to determine the kinetic parameters for free and immobilized laccases using ABTS as substrate. The effect of immobilization on diffusion of substrate and product formation was determined using effectiveness factor (EF). $K_{\mathrm{m}}$ and $V_{\max }$ values were calculated by intercepting the line on the Xaxis and Y-axis using ABTS as substrate. Immobilized laccase had a higher $K_{\mathrm{m}}$ value than soluble laccase (Figure 6). Laccase in 1:2 and 1:5 T:P ratios had 83 and $100 \mathrm{mM}$ value of $K_{\mathrm{m}}$ respectively as compared to 33 $\mathrm{mM}$ for free laccase. The EF value of 16 (lower than soluble) indicated that there was negligible diffusion of substrate and product removal from the gel-entrapped laccases. Immobilization offered resistance to diffusion and increased the capacity to capture a high concentration of product inside the gel. However, it could be inferred that low diffusion of substrate was the major cause of the high $K_{\mathrm{m}}$ and immobilization hindered the conformational change of catalyst that was also shown by the high $V_{\max }$. Furthermore, lower $K_{\mathrm{m}}$ for substrate indicated that it had high affinity for its substrate and lower value of $V_{\max }$ indicated that a small amount of enzyme can convert substrate into the product. Catalytic activity for free and immobilized laccase was $0.92 \mathrm{~S}^{-1} \mathrm{M}^{-1}$, $0.85 \mathrm{~S}^{-1} \mathrm{M}^{-1}$ for 1:2, 1:5 T:P ratio and $1.27 \mathrm{~S}^{-1} \mathrm{M}^{-1}$ for free laccase respectively.

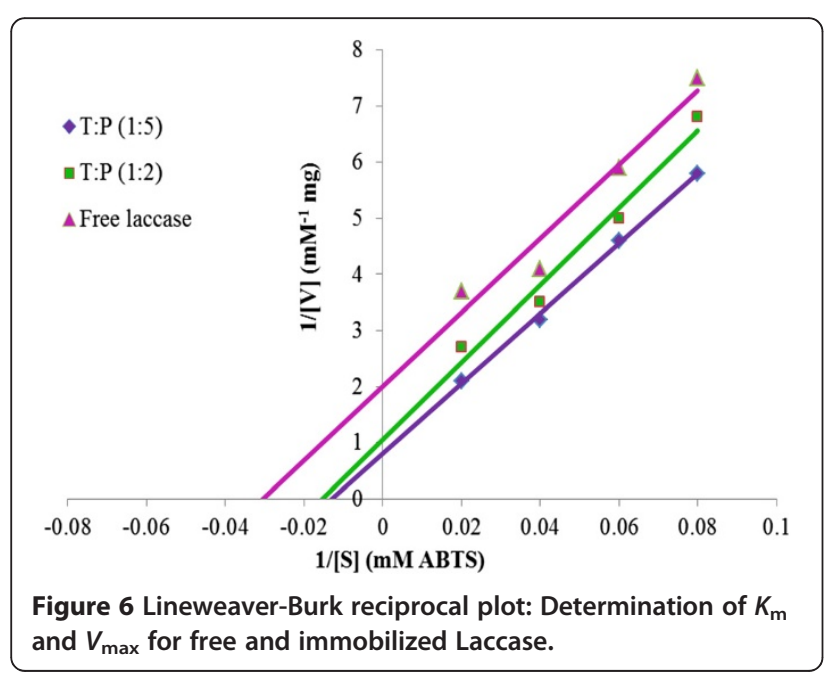

Although immobilized laccases have higher $K_{\mathrm{m}}$ values than soluble counterparts, the immobilized laccase have been proved to have excellent reusability, thermal constancy and equipped permanence due to high $V_{\max }$ [24]. The $K_{\mathrm{m}}$ value indicates the interaction of enzyme with its substrate. Rekuc et al. [26] immobilized laccase in cellular foams and found that $K_{\mathrm{m}}$ for the soluble and entrapped laccase were 39.4, 133.4 and the $K_{\text {cat }}$ for free and immobilized laccase was 86 and 117. Wang et al. [31] reported that laccase, after immobilizing in silica nano-particles, showed $3.28 \mathrm{mM}$ and $155.4 \mathrm{~min}^{-1}, K_{\mathrm{m}}$ and $K_{\text {cat }}$ respectively.

\section{Decolorization of Textile dyes and effluents}

Free and immobilized laccases from $P$. ostreatus showed different decolorization profiles for different dye-stuffs. It was noted that immobilized laccase was more efficient decolorizer of all reactive dyes as compared to its free counterpart. The best decolorization results (100\%) were observed for Drimarine blue K2RL (Figures 7 and 8). In case of industrial effluents the CRT effluent was completely decolorized by immobilized laccase, followed by $97 \%$ decolorization of SIT effluent after $5 \mathrm{~h}$ of incubation with ABTS as mediator (Figures 9 and 10). The decolorization of other effluents was also significantly higher for immobilized laccase as compared to free enzyme and ABTS was found to enhance the dye decolorization capacities of both free and immobilized laccase.

Laccases have been considered as the major dye degrading enzymes and are efficient decolorizers of dyes present in industrial wastewaters [32]. The ability of laccases to decolorize dye containing effluents is correlated to its ability to degrade different dyes present in the effluent. Immobilization modifies the activity, selectivity, and equipped permanence of enzymes. Immobilized

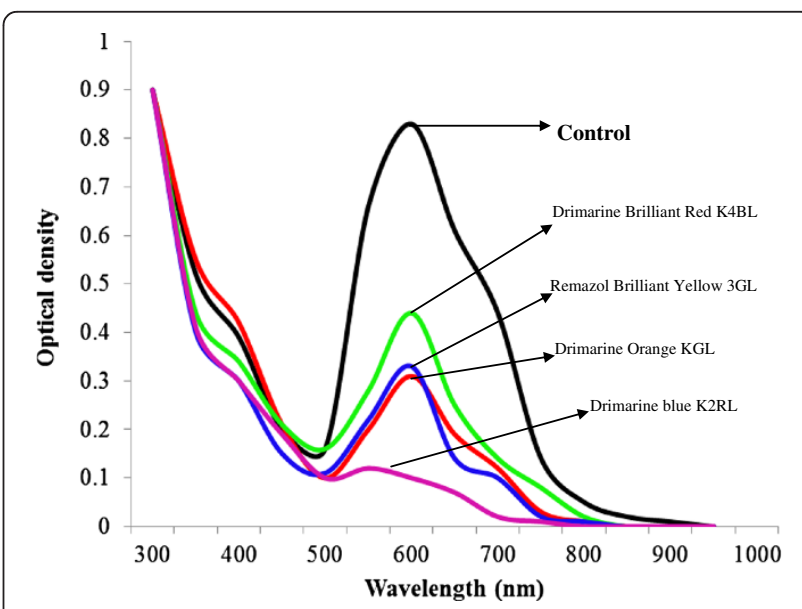

Figure 7 UV-vis absorption spectra of textile dyes obtained after $5 \mathrm{~h}$ treatment with free laccase. 


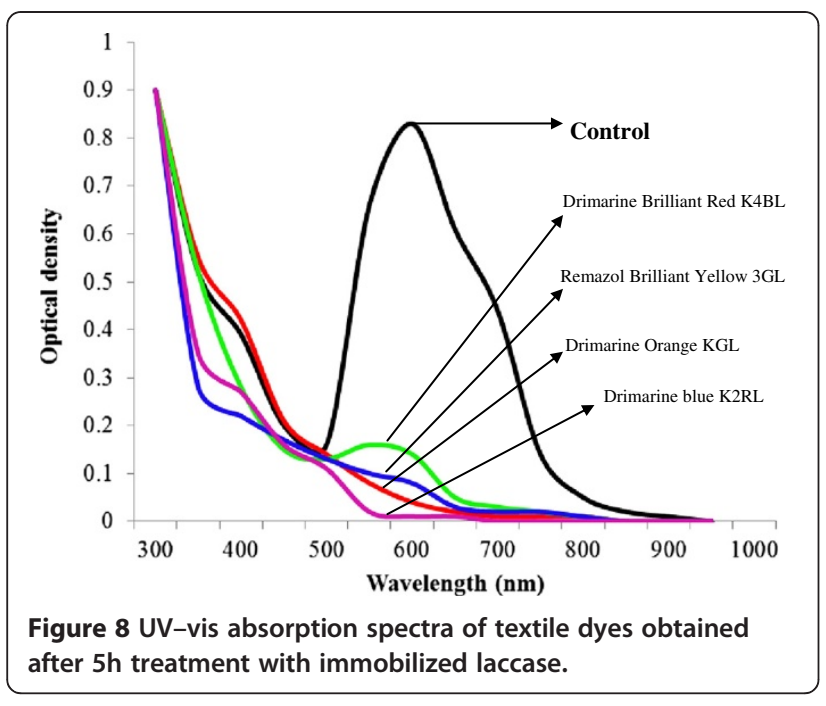

laccases are more robust dye degraders as compared to their free counterparts [33]. The variation in effluent composition is responsible for the difficulty of its decolorization by enzyme extracts from different fungi [34]. The present sol-gel matrix-entrapped laccase seems to have potential capabilities to meet the challenges of modern industrial sector, especially for bioremediation in the textile industry.

\section{Conclusions}

Laccase isolated from an indigenous fungal strain $P$. ostreatus IBL-02 was immobilized by Sol-gel entrapment with an objective to improve its catalytic and thermostability and reusability. Hydrophobic gel entrapment resulted in increased half-life, $V_{\max }$ and $K_{\mathrm{m}}$ values for the enzyme that may be desirable characteristics for its industrial applications. Moreover, the Sol-gel entrapped laccase presented potential efficiency as a biocatalyst for

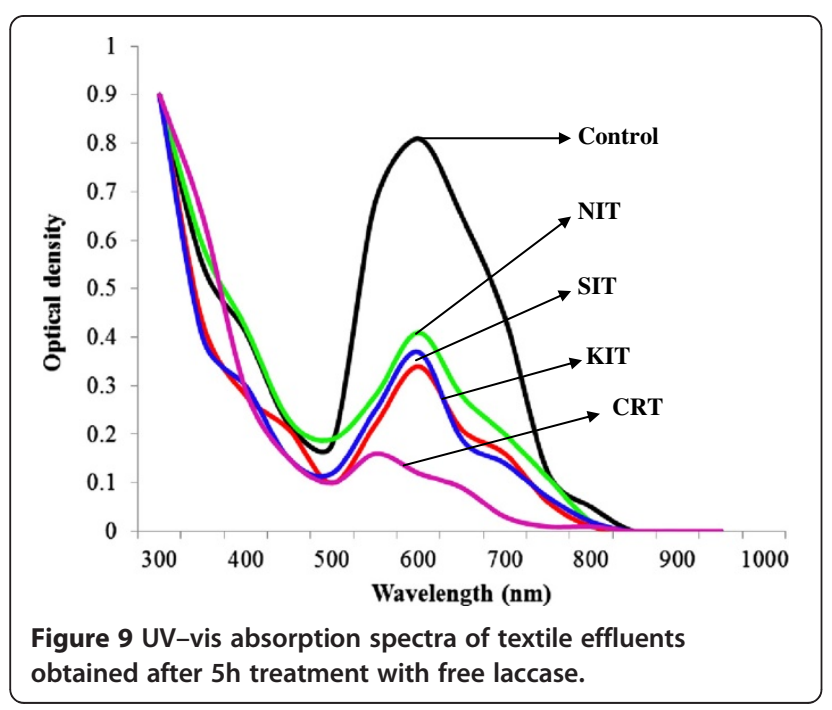

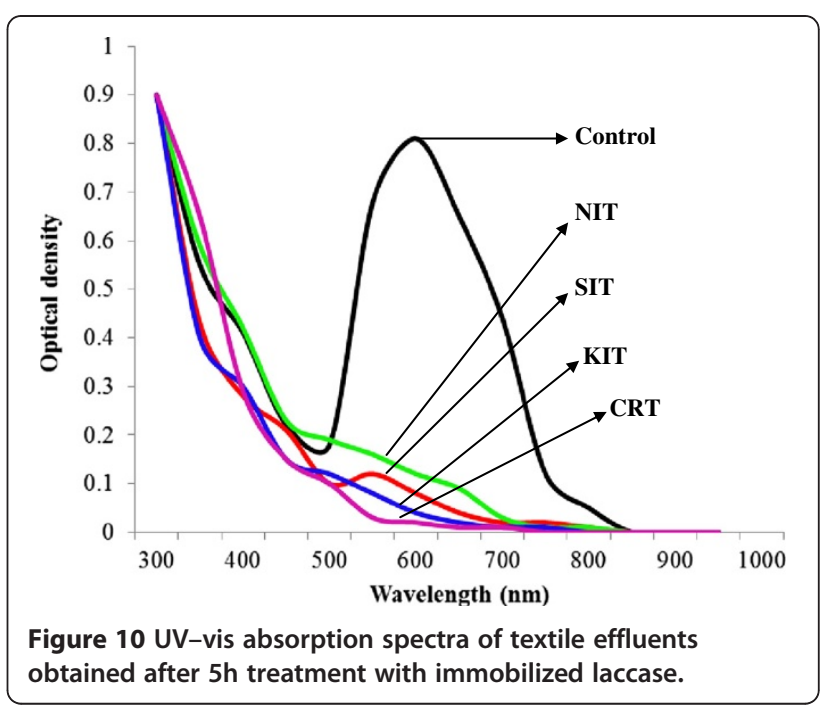

the decolorization of different dyes and local textile wastewaters. The main benefits of the Sol-gel matrix immobilization processes are the eco-friendly approach, chemical free and energy saving reaction conditions. In view of the long term trend of striving for more environmental friendly industrial processes, the health concerns regarding harmful chemicals, the versatility, non-toxicity and mild reaction conditions, the Sol-gel immobilization technology is likely to remain the subject of intensive research investigations in different sectors of industrial and environmental biotechnology.

\section{Experimental \\ Chemicals}

Trimethoxysilane, proplytetramethoxysilane, polyvinyl alcohol, Sephadex G-100, 2, 2/-azino-bis-3-ethylbenzothiazoline-6-sulfonic acid (ABTS), Coomassie Brilliant Blue G-250, sodium dodecylsulphate (SDS), trizma base and standard Protein markers were purchased from Sigma-Fluka-Aldrich (USA). All other chemicals were of analytical grade and were mainly purchased from Merck (Germany) and Scharlau (Spain). For decolorization studies, four different dyes and textile industry effluents were collected onsite from local textile industries in Faisalabad, Pakistan.

\section{Source of laccase}

In a previous study, an indigenous novel strain $P$. ostreatus IBL-02 was found to produce substantial amount of laccase as a major enzyme during decolorization of the reactive textile dye Drimarene Brilliant Red K- 4BL. For maximum laccase production and dye decolorization, the physical and nutritional growth conditions have also been optimized [17]. Laccase was therefore produced under pre-optimized conditions for purification and immobilization studied. 


\section{Laccase activity assay}

Laccase activities in the collected samples were determined at room temperature by the UV/Vis spectrophotometric assay [8]. The activity of laccase was determined by monitoring the ABTS oxidation in a reaction mixture containing $1 \mathrm{ml}$ of $1 \mathrm{mM}$ ABTS and $1 \mathrm{ml}$ of $50 \mathrm{mM}$ malonate buffer $(\mathrm{pH} 4.5)$ and $100 \mu \mathrm{L}$ of culture supernatant. The reaction mixture was incubated at $25^{\circ} \mathrm{C}$ and absorbance of each sample was taken at $420 \mathrm{~nm}$ after 10 min. Blanks contained $100 \mu \mathrm{L}$ of distilled water instead of enzyme solution or culture supernatant. Laccase activity was expressed as international units (IU) and defined as the amount of enzyme forming $1 \mu \mathrm{mol}$ of ABTS.+ per min under the assay conditions.

\section{Protein estimation}

Proteins were estimated using the Bradford micro assay [35] using bovine serum albumin (BSA) as standard. To $1 \mathrm{~mL}$ of Bradford reagent, $100 \mu \mathrm{L}$ of each solution were added and mixed on a vortex mixer. The reagent blank was run by adding $100 \mu \mathrm{L}$ of distilled water to $1 \mathrm{~mL}$ of the Bradford reagent. The change in absorbance $(\Delta \mathrm{A})$ at $595 \mathrm{~nm}$ for all samples was determined within 15-30 min.

\section{Purification of laccase}

The culture filtrate was first filtered and centrifuged at $3000 \times \mathrm{g}$ and supernatant was then subjected to ammonium sulfate precipitation. The precipitate obtained was dialyzed and lyophilized and then loaded onto a DEAESepharose anion-exchange column $1.5 \times 18 \mathrm{~cm}$, equilibrated with $10 \mathrm{mM}$ sodium acetate buffer ( $\mathrm{pH} 4.5)$, with a linearly increasing $\mathrm{NaCl}$ concentration gradient $(0$ to $0.5 \mu \mathrm{M})$ in the same buffer. The six fractions containing laccase activity were pooled, concentrated, and dialyzed overnight against same buffer. Gel filtration chromatography was performed using sephadex G-100 column $2.0 \times 40 \mathrm{~cm}$. The DEAE-purified sample was loaded on to the column and $3 \mathrm{~mL}$ fractions were collected. The eluted active fractions were dialyzed and protein content was determined by Bradford method.

\section{Native and SDS-PAGE}

The purified and lyophilized sample was dissolved in a minimum amount of $50 \mathrm{mM}$ malonate buffer, and subjected to $12 \%$ native PAGE and 10\% SDS-PAGE using a Vertical Minigel electrophoresis apparatus (V-GES, Wealtec Corporation, U.S.A) to determine sample purity and approximate mass of laccase [36]. The approximate molecular mass of the laccase was determined after gel staining with Coomassie Brilliant Blue G followed by the calibration against broad-range molecular weight markers (Sigma, USA), which contained proteins ranging from $21-116 \mathrm{kDa}$.

\section{Preparation of hydrophobic gels and immobilization of laccase}

To prepare the Sol-gel thin films for enzyme entrapment purposes, TMOS and PTMS were used in different molar TMOS: PTMS (T: P) ratios by adopting the methodology as described earlier by Asgher et al. [10]. TMOS and PTMS were used in molar T: P ratios of 1:1, 1:5, $1: 10,1: 15,1: 20$ and 1:25 to prepare gels of different hydrophobicity, in ascending order. Laccase isolated from P. ostreatus IBL-02 was suspended in water (12.5 $\mathrm{mg} / \mathrm{mL}$ ), shaken for $5 \mathrm{~min}$ and centrifuged. The supernatant fluid $(400 \mu \mathrm{L})$ was added to a mixture of polyvinyl alcohol and water. The solution was shaken and PTMS was added, followed by TMOS. The reaction mixture was vigorously shaken for $5 \mathrm{sec}$ on a vortex mixer and then gently shaken by hand. After about $30 \mathrm{sec}$, when the mixture formed a clear homogenous solution, it was placed in an ice bath until gel formation occurred. Laccase activity and protein contents of entrapped enzymes (in gels of different hydrophobicity) were determined. The entrapped enzymes having highest specific enzyme activity and protein contents were selected for further characterization.

\section{Characterization/Comparison of free and immobilized laccases}

Purified native and Sol-gel entrapped laccases were characterized to determine and compare their $\mathrm{pH}$ and temperature optima, and kinetic constants such as $V \max$ (maximum rate), Km (Michaelis constant) and Kcat (catalytic efficiency).

\section{Effect of immobilization on optimum $\mathrm{pH}$}

The activities of purified native and entrapped laccases were studied over a $\mathrm{pH}$ range of 2.0-10.0 using ABTS as substrate. The buffers $(0.1 \mathrm{M})$ used were: $\mathrm{pH} 2-2.8$, tartaric acid/sodium tartrate; $\mathrm{pH} 3-3.6$, glycine/ $\mathrm{HCl}$ ); $\mathrm{pH}$ 3.8-4.5, glutamic acid/HCl; $\mathrm{pH} 4.6-6.0$ sodium acetate/ acetic acid; $\mathrm{pH} 6-7$, sodium phosphate; $\mathrm{pH} 7.5-8$, Tris$\mathrm{HCl}$; and $\mathrm{pH} 9-10$, glycine- $\mathrm{NaOH}$ buffer.

\section{Effect of immobilization on optimum temperature and thermo-stability}

The temperature activity profile of free and entrapped laccase was determined at different temperatures ranging from $25-75^{\circ} \mathrm{C}$ for $30 \mathrm{~min}$. For determination of half-lives the enzymes were incubated at $60^{\circ} \mathrm{C}$ for varying time periods before carrying out standard laccase assay.

\section{Effect of immobilization on kinetic constants $\mathrm{Km}, \mathrm{Vmax}$ and Kcat}

The Michaelis-Menten kinetic constants including $K_{\mathrm{m}}$, $V_{\max }$ and $K_{\text {cat }}$ were determined by using varying 
concentrations of ABTS ranging from 0.1-1 mM. Laccase activity was determined for each concentration of ABTS keeping enzyme concentration constant. LineweaverBurk plots were constructed between reciprocals of the initial reaction rates $\left(1 / \mathrm{V}^{\mathrm{o}}\right)$ and varying substrate concentrations $[1 / \mathrm{S}]$.

\section{Applications of free and immobilized laccase Decolorization of dyes}

Free and immobilized laccases were used for the decolorization of four reactive textile dyes (Drimarine Blue K2RL; Drimarine Orange KGL; Drimarine Brilliant Red K4BL and Remazol Brilliant Yellow 3GL). The working conditions of a single continuous operation were: two parallel batch of triplicate flasks containing 10 $\mathrm{mL}$ of free and $5 \mathrm{~g}$ of sol-gel-entrapped biocatalyst (laccase) was transferred to $100 \mathrm{~mL}$ of $0.01 \%$ individual dye solutions with $1 \mathrm{~mL}$ of $1 \mathrm{mM}$ ABTS as a laccase mediator followed by the incubation at $25^{\circ} \mathrm{C}$ for $5 \mathrm{~h}$ in rotary shaker $(120 \mathrm{rpm})$. The culture supernatants recovered after filtration and centrifugation of the enzyme treated samples collected after every each hour were subjected to the residual dyestuff analysis. Absorbance measurements were done by a UV-Visible spectrophotometer (T-60, PG instruments, UK). The absorbance values for respective supernatants at each time period were corrected by subtracting the values for respective control fraction (containing only the reaction medium without enzyme). Decolorization of dye solution was determined by a reduction in optical density at the wavelength of maximum absorbance at $\lambda \max (590 \mathrm{~nm})$ by UV-vis spectrophotometric spectrum.

\section{Decolorization of real textile industry effluents}

Different dye containing practical textile industry effluents of different colors were collected from Sitara textile (SIT), Nishat textile (NIT), K\&N textile (KNT) and Crescent textile (CRT) units of Faisalabad. The effluent source industries did not disclose the names and structures of dyes being used due to their business secrets. The working conditions of a single continuous operation were: two parallel batches of triplicate flasks containing $10 \mathrm{~mL}$ of free and $5 \mathrm{~g}$ of sol-gel-entrapped laccase, respectively, $100 \mathrm{~mL}$ of individual dye solutions/textile effluents with $1 \mathrm{~mL}$ of $1 \mathrm{mM}$ ABTS as laccase mediator, and incubated at $30^{\circ} \mathrm{C}$ in shaking incubator $(120 \mathrm{rpm})$ for $5 \mathrm{~h}$ reaction time. The samples collected at one $\mathrm{h}$ intervals from each flask were used to determine the percentage color removal of textile dyes and effluents by considering the initial and final effluent absorbance. All the collected samples were centrifuged at 5,000 $\times$ g for 15 min at room temperature $\left(25^{\circ} \mathrm{C}\right)$ and clear supernatants were analyzed spectrophotometrically. Decolorization of individual effluents was determined by a reduction in optical density at the wavelength of maximum absorbance $(\lambda \max )$.

\section{Competing interests}

The authors have no competing interests.

\section{Authors' contributions}

HMNI (Research Associate of the project) and SK (PhD Research Student) participated in carried out the experimental work on microbial cultivation, laccase production, extraction, purification, Sol-gel immobilization and kinetic characterization of free and immobilized Laccase. They also participated in drafting the manuscript. All the research work was carried out under the supervision of MA (Principal Investigator of the project), who designed the project and supervised all the experimental and analytical work. All authors read and approved the manuscript before submission.

\section{Acknowledgements}

The present study was a part of the research project funded by Higher Education Commission (HEC), Islamabad, Pakistan under National Research Program for Universities (NRPU). The timely provision of Funds by HEC is highly acknowledged.

Received: 7 August 2012 Accepted: 27 September 2012

Published: 29 September 2012

\section{References}

1. Wesenberg D, Kyriakides I, Agathos SN: White-rot fungi and their enzymes for the treatment of industrial dye effluents. Biotechnol Adv 2003, 22:161-187.

2. Colao MC, Lupino S, Garzillo AM, Buonocore V, Ruzzi M: Heterologous expression of Icc1 gene from Trametes trogii in Pichia pastoris and characterization of the recombinant enzyme. Microb Cell Fact 2006, 5:31.

3. Asgher M, Bhatti HN, Ashraf M, Legge RL: Recent developments in biodegradation of industrial pollutants by white rot fungi and their enzyme system. Biodegradation 2008, 19:771-783.

4. Kim J-M, Park S-M, Kim D-H: Heterologous expression of a tannic acidinducible laccase3 of Cryphonectria parasitica in Saccharomyces cerevisiae. BMC Biotechnol 2010, 10:18.

5. Stoilova I, Krastanov A, Stanchev V: Properties of crude laccase from Trametes versicolor produced by solid-substrate fermentation. Adv Biosci Biotechnol 2010, 1:208-215.

6. Asgher M, lqbal HMN: Characterization of a novel manganese peroxidase purified from solid state culture of Trametes versicolor IBL-04. BioRes 2011, 6:4317-4330.

7. Reiss R, Ihssen J, Thöny-Meyer L: Bacillus pumilus laccase: a heat stable enzyme with a wide substrate spectrum. BMC Biotechnol 2011, 11:9.

8. Asgher M, labal HMN, Asad MJ: Kinetic characterization of purified laccase produced from Trametes versicolor IBL-04 in solid state bio-processing of corncobs. BioRes 2012, 7:1171-1188.

9. Kunamneni A, Camarero S, García-Burgos C, Plou FJ, Ballesteros A, Alcalde $\mathrm{M}$ : Engineering and Applications of fungal laccases for organic synthesis. Microb Cell Fact 2008, 7:32.

10. Asgher M, lqbal HMN, Irshad M: Characterization of purified and Xerogel immobilized Novel Lignin Peroxidase produced from Trametes versicolor IBL-04 using solid state medium of corncobs. BMC Biotechnol 2012, 12:46.

11. Cheng J, Randall A, Baldi M: Prediction of Protein Stability Changes for Single-Site Mutations Using Support Vector Machines. Prot Str Func Bioinf 2006, 62:1125-1132.

12. Almeida VM, Branco CRC, Assis SA, Vieira IJC, Braz-Filho R, Branco A: Synthesis of naringin 6"-ricinoleate using immobilized lipase. Chem Central J 2012, 6:41.

13. Iqbal HMN, Asgher M: Characterization and decolorization applicability of xerogel matrix immobilized manganese peroxidase produced from Trametes versicolor IBL-04. Protein Pept Lett 2012, In-Press, PPL-EPUB20120925-3.

14. Irshad M, Bahadur BA, Anwar Z, Yaqoob M, ljaz A, labal HMN: Decolorization applicability of sol-gel matrix-immobilized laccase produced from Ganoderma leucidum using agro-industrial waste. BioRes 2012, 7(3):4249-4261. 
15. Saratale RG, Saratale GD, Chang JS, Govindwar SP: Outlook of bacterial decolorization and degradation of azo dyes: a review. J Taiwan Inst Chem Eng 2011, 42:138-157.

16. Asgher M, Asad MJ, Bhatti HN, Legge RL: Hyperactivation and thermostabilization of Phanerochaete chrysosporium lignin peroxidase by immobilization in xerogels. World J Microbiol Biotechnol 2007, 23:525-531

17. Kamal S, Asgher M, Khalil-ur-Rehman, Zahir ZA: Hyperproduction of laccase by Pleurotus ostreatus IBL-02 during decolorization of drimarene brilliant red K-4BL. Fresen Environ Bull 2011, 20:1478-1486.

18. Chen S, Ge W, Buswell JA: Biochemical and molecular characterization of a laccase from the edible straw mushroom Volvariella volvacea. Eur J Biochem 2004, 271:318-328.

19. Mansur M, Arias ME, Patino JLC, Gonzalez MFAE: The white-rot fungus Pleurotus ostreatus secretes laccase isozymes with different substrate specificities. Mycologia 2003, 95:1013-1020.

20. Miao L, Zhang G, Wang H, Ng T: Purification and Characterization of a Laccase from the edible wild mushroom Tricholoma mongolicum. J Microbiol Biotechnol 2010, 20:1069-1076.

21. Nagai M, Sato T, Saito K, Kawata M: Purification and characterization of an extracellular laccase from the edible mushroom Lentinula edodes, and decolorization of chemically different dyes. Appl Microbiol Biotechnol 2002, 60:327-335.

22. Du Z, Sun XB: Purification and characterization of laccase from Curvularia trifol. Adv Mat Res 2010, 116:2215-2219.

23. Perez J, Rubia TD, Hamman OB, Martinez J: Phanerochaete flavidoalba laccase induction and modification of manganese peroxidase is enzyme pattern in decolorized olive oil mill wastewaters. Appl Environ Microbiol 1998, 64:2722-2729

24. Qiu H, Xu C, Huang X, Ding Y, Qu Y, Gao P: Immobilization of laccase on nanoporous gold: comparative studies on the immobilization strategies and the particle size effects. J Phys Chem 2009, 113:2521-2525.

25. Clifford JS, Legge RL: Use of water to evaluate hydrophobicity of organically-modified Xerogel enzyme supports. Biotechnol Bioeng 2005, 92:231-237

26. Rekuc A, Bryjak J, Szymanska K, Jarzebski AB: Laccase immobilization on mesostructured cellular foams afford preparations with ultra-high activity. Proc Biochem 2009, 44:191-198.

27. Huang J, Liu Y, Wang $X$ : Silanized palygorskite for lipase immobilization. J Mol Catal B: Enz 2009, 57:10-15.

28. Arica M, Altıntas B, Bayramoglu G: Immobilization of laccase onto spacerarm attached non-porous poly(GMA/EGDMA) beads: Application for textile dye degradation. Biores Technol 2009, 100:665-669.

29. Singh G, Bhalla A, Capalash N, Sharma P: Characterization of immobilized laccase from $\gamma$-proteobacterium JB: Approach towards the development of biosensor for the detection of phenolic compounds. Indian J Sci Technol 2010, 2:48-53.

30. Prasad KK, Mohan SV, Bhaskar YV, Ramanaiah SV, Babu VL, Pati BR, Sarma PN: Laccase production using Pleurotus ostreatus 1804 immobilized on PUF cubes in batch and packed bed reactors: influence of culture conditions. J Microbiol 2005, 43:301-307.

31. Wang F, Guo C, Yang L, Liu CZ: Magnetic mesoporous silica nanoparticles: Fabrication and their laccase immobilization performance. Biores Technol 2010, 101:8931-8935.

32. Pazarlioglu NK, Sariisik M, Telefoncu A: Laccase production by Trametes versicolor and application to denim washing. Proc Biochem 2005, 40:1673-1678.

33. Bayramoglu G, Yilmaz M, Arica MY: Reversible immobilization of laccase to poly(4-vinylpyridine) grafted and $\mathrm{Cu}(\mathrm{II})$ chelated magnetic beads: Biodegradation of reactive dyes. Biores Technol 2010, 101:6615-6621.

34. Maas R, Chaudhari S: Adsorption and biological decolorization of azo dye reactive red 2 in semicontinuous anaerobic reactors. Proc Biochem 2005, 40:699-705.
35. Bradford MM: A rapid and sensitive method for quantification of microgram quantities of protein utilizing the principle of protein dye binding. Anal Biochem 1976, 72:248-254.

36. Laemmli UK: Cleavage of structural proteins during assembly of head of bacteriophage T4. Nature 1970, 227:680-685.

doi:10.1186/1752-153X-6-110

Cite this article as: Asgher et al.: Improvement of Catalytic Efficiency, Thermo-stability and Dye Decolorization Capability of Pleurotus ostreatus IBL-02 laccase by Hydrophobic Sol Gel Entrapment. Chemistry Central Journal 2012 6:110.

\section{Publish with ChemistryCentral and every scientist can read your work free of charge \\ "Open access provides opportunities to our colleagues in other parts of the globe, by allowing anyone to view the content free of charge." \\ W. Jeffery Hurst, The Hershey Company. \\ - available free of charge to the entire scientific community \\ - peer reviewed and published immediately upon acceptance \\ - cited in PubMed and archived on PubMed Central \\ - yours - you keep the copyright \\ Submit your manuscript here: \\ http://www.chemistrycentral.com/manuscript/<smiles>c1ccccc1</smiles> \\ Chemistry Central}

